21. Яворницький Д. І. Історія запорозьких козаків: у 3 т. / Д. І. Яворницький. - Київ: Наук. думка, 1990-1993. - Т. 3. - 415 с.

22. Corothers T. Civil Society / T. Corothers // Forein Polisy. - № 117, Winter 1999-2000. - P. 18-29.

Надійшла до редкол.: 19.11.2017

\title{
Історична і соціальна пам'ять: спільне та особливе
} Ковальська-Павелко І. М. Дніпровський національний університет імені Олеся Гончара

Встановлено, що на початкових етапах становлення меморіальних концептів історичну і соціальну пам'ять здебільшого ототожнювали, вважаючи їх зрізами колективної пам'яті, проте поступово почало викристалізовуватися розуміння можливості і потреби в проведенні демаркації між даними концептами.

Ключові слова: колективна пам'ять; історична реконструкція; соціальна пам'ять; історична пам'ять; типи; форми; рівні соціальної пам'яті; соціальна амнезія

Установлено, что на начальных этапах становления мемориальных концептов историческую и социальную память в основном отождествляли, считая их срезами коллективной памяти, однако постепенно начало выкристаллизовываться понимание возможности и потребности в проведении демаркации между данными концептами.

Ключевые слова: коллективная пам'ять; историческая реконструкція; социальная память; историческая пам'ять; типы; формы; уровни социальной памяти; социальная амнезия

It was established that in the initial stages of the formation of memorial concepts historical and social memory was mostly identified, considering them as a cut of collective memory, but gradually began to crystallize the understanding of the possibility and need for demarcation between these concepts. It is stated that today it is accepted to define social memory as a form of translation of the symbolic capital of certain social groups; she is the spokesman for group values, ideas, guidelines and in this sense acts as the bearer of the norms and values of social groups, accumulates and retains social capital and ensures its use in the processes of communication and reproduction of accumulated social information, and historical memory - as a set of pre-scientific, scientific, quasi-scientific and non-scientific knowledge and mass representations of society about the common past. 
The official and unofficial levels of social memory are allocated. The features of official memory is that it is formed purposefully from above; has a systemic character; based on dominant ideology; is formed predominantly by constructing; mainly through official channels; its carriers are school textbooks and official media; supported by the authorities. Unofficial memory has the following features: it is formed spontaneously from below; fragmentary nature; is based on the phenomenon of susp. memories; formed predominantly by reconstruction; extends mainly through interpersonal contacts; its carriers are archetypes, myths, legends, fairy tales, rumors, gossip, jokes, etc.; supported by informal structures. It is shown that the most expressive ratio of historical and social memory manifests itself at the individual level, when the events of the past are reproduced through the prism of personal interests or interests of certain social groups, which makes possible the value-symbolic reconstruction of the past in the present. It has been found out that social memory plays an important protective role in the traumatic scenes of historical memory, which manifests itself in social amnesia when there is a removal from the memory of unwanted events of the past.

Keywords: collective memory; historical reconstruction; social memory; historical memory; types; forms; levels of social memory; social amnesia

Сьогодні розкриття взаємозв'язку історичної та соціальної пам'яті $є$ важливим для української суспільної науки та практики питанням, актуальність якого загострюється конфліктогенними за своєю природою і болючими за своїм емоційним наповненням для багатьох поколінь українців характером національно-культурним піднесенням на хвилі підйому патріотичних настроїв у ході Революції гідності, євроінтеграційних прагнень, процесів декомунізації та децентралізації, транскордонних проблем на західних територіях та ін. У цілому актуальність вивчення взаємовпливу історичної і соціальної пам'яті обумовлена сучасним кризовим станом українського суспільства, в якому спостерігаються розрив споконвічних зв'язків, перегляд історичних подій, відрив від духовних коренів, забуття традиційних цінностей і нехтування моралі.

Ще один із фундаторів меморіальної проблематики Моріс Альбвакс у своїх головних працях «Соціальні рамки пам'яті» i «Колективна пам'ять» наголошував, що саме через членство і належність до соціальної групи особистість здатна набувати, локалізувати і витягати з пам'яті свої спогади. Він вважав, що не існує колективної (тобто соціальної) пам'яті там, де немає посилання на специфічну в соціальному плані базову просторову структуру. Наші образи соціальних просторів саме через свою відносну стабільність створюють ілюзію незмінюваності та можливість «відкривати заново» минуле в нашому теперішньому (див.: [9, с. 325-343]). 
Проблема співвідношення історичної та соціальної пам'яті достатньо добре розроблена у полі історичних, філософських, соціологічних і психологічних наук. Проте єдиної думки щодо концептуальної визначеності цього питання немає. Наукове осмислення феномену суспільної (в т. ч. історичної й соціальної) пам'яті у західному суспільствознавстві пов'язане з т. 3. «memory-studies», біля джерел яких стояли П. Рікьор, К. Юнг, Т. Адорно, Е. Фромм, Е. Дюркгейм та інші «класики». Останнім часом, спираючись на доробки західних учених М. Альбвакса, Я. Ассман, М. Блева, Х. Вельцер, Е. Гобсбаума, К. Дефанс, П. Коннертона, Д. Лоуенталя, П. Нора, М.Оукшотом, У.Пфайля, В. Розу,Й.Рюзена, Б. Стора, Ю.Шеррер та ін., вітчизняні науковці В. Артюх, О. Волянюк, В. В'ятрович, Р. Голик, М. Гона, В. Городяненко, Л. Дробіжева, Ю. Зерній, О. Злобіна, В. Карлова, А. Киридон, В. Колеватов, І. Колесник, Г. Корж, В. Масненко, Л. Нагорна, Е. Позднякова-Кирбят'єва, А. Полетаєв, Т. Полтавчук, В. Полянський, І. Савельєва, В. Середа, В. Солдатенко, Ю. Сорока, В. Тихонович, О. Удод, О. Фостачук, С. Хутка та ін. репрезентували свої версії розв'язання даної проблеми.

Отже, метою цієї статті є розкриття спільних та особливих рис історичної та соціальної пам'яті.

Зараз соціальну пам'ять прийнято визначати як форму трансляції символічного капіталу певних соціальних груп; вона є виразником групових цінностей, уявлень, настанов і в цьому значенні виступає носієм норм та цінностей соціальних груп, накопичує та зберігає соціальний капітал і забезпечує його використання в процесах спілкування й відтворення накопиченої соціальної інформації. Історичну ж пам'ять визначають як сукупність донаукових, наукових, квазінаукових і ненаукових знань та масових уявлень соціуму про спільне минуле. Як складний феномен суспільної свідомості вона містить певні образи, символи, міфи, ритуали, історіографічні уявлення.

На Заході проблема співвідношення та взаємообумовленості історичної та соціальної пам'яті була започаткована вже згадуваним французьким соціологом Морісом Альбваксом, який у 1925 р. стверджував, що простір, час і колективна пам'ять взаємозв'язані; колективна (або соціальна) пам'ять вкорінена в конкретний соціальний досвід i, отже, тісно пов'язана з часовими й просторовими уявленнями. Він визначив колективну пам'ять як соціальний феномен, необхідний для функціонування й виживання суспільства, те спільне, що конституює суспіль- 
ство та є запорукою його ідентичності. Він вважає, що пам'ять завжди і всюди соціально зумовлена і маркована, навіть на індивідуальному рівні сприйняття й формування ії образів. На думку М. Альбвакса, «складний процес взаємодії спогаду й повторення як основи функціонування пам'яті зумовлює виникнення узагальнених ідеальних образів, на основі яких формуються концептуальні схеми або «соціальні рамки», у яких розміщуються індивідуальні спогади. Кожна соціальна група створює пам'ять про своє минуле, що, в свою чергу, формує і відображає ідентичність цієї групи стосовно інших груп [8, с. 12].

Тобто меморіальні феномени він класифікує на індивідуальну і колективну, або на автобіографічну й історичну, або на особистісну i соціальну пам'ять. Отже, для М. Альбвакса колективна, історична і соціальна пам'ять $є$ тотожними. Він стверджував: «Якщо під історичною пам'яттю ми розуміємо низку подій, спогади про які зберігає національна історія, то чи не вона, чи не ії рамки є основною частиною того, що ми називаємо колективною пам'яттю?» [8, с. 12-13]. Історичний характер соціальної пам'яті полягає, насамперед, в тому, що «історія не лише продукує розповіді сучасників про події минулого, але час від часу і корегує їх - не лише тому, що володіє іншими доказами, але й для того, щоб пристосувати їх до прийомів мислення і репрезентації, які притаманні су-часним людям» [9, с. 209].

Роблячи наголос на соціальних рамках пам'яті, що сприяють створенню образів минулого відповідно до історичної епохи та ідей, які домінують у певному суспільстві, М. Альбвакс зазначав, що формування соціальної пам'яті відбувалося як явище ритуалізованої, колективної пам'яті, тобто такої, яка виявляється у соціальній детермінованості ціннісної реконструкції минулого в теперішньому [9, с. 28-29]. При цьому вчений стверджував, що механізми відтворення соціальної пам'яті включають спогади і традиції. Спогади $\epsilon$ реконструкцією минулого, оскільки відбувається деформація, викривлення минулого в свідомості людини в процесі пригадування і переосмислення, бо «піднімаючись на поверхню, наші спогади ніби перетворюються, змінюють вигляд, псуються під дією інтелектуального світла» [9, с. 56].

Наслідуючи М. Альбвакса, інший французький учений П'єр Нора вважає, що соціальна пам'ять знаходиться в «постійному процесі еволюції». Результатом трансформації соціальної пам'яті $\epsilon$ історична пам'ять, ознаками якої є індивідуальність, суб'єктивність і продуманість. Ї̈̈ трансформація може відбуватись за допомогою двох механізмів: 
- вплив певних соціальних груп або державних органів на формування культури пам'яті нації;

- зміни, що виникають в процесі еволюції соціальних інститутів.

Спираючись на аналіз ставлення до минулого, П. Нора виділяє три категорії пам'яті: пам'ять-архів, пам'ять-борг i пам'ять-дистанція, що функціонально відрізняються між собою. У свою чергу, ключовим поняттям, що дозволяє проаналізувати механізми соціальної пам'яті, виступають місця пам'яті. Місця пам'яті - це будь-яка значуща єдність матеріального чи ідеального порядку, яку воля людей чи робота часу перетворили на символічний елемент спадщини пам'яті деякої спільноти» [6, с. 441]. П. Нора стверджує, що місця (простори) пам'яті є не лише географічними пунктами, а і своєрідними точками зіткнення, в яких формується і комеморизується пам'ять суспільства. Тут комеморизація - це спосіб, за допомогою якого укріплюється i передається пам'ять про минуле. Головна функція цих «місць» полягає у збереженні групової пам'яті. Як місця пам'яті виступають люди, події, споруди, традиції, пісні або ландшафтні одиниці, оточені символічною аурою. Ці місця мають символічне значення, яке може змінюватись під впливом численних індивідуальних чи групових стратегій. П. Нора вважає, що створення й усвідомлення особистістю «місць пам'яті» $є$ головним чинником формування групової ідентичності. Досліджуючи зміну цих місць, можна простежити зміну історичної самосвідомості й колективної ідентичності певної соціальної групи. Ці зміни можуть відбуватися як через забуття й витискування певного «місця» із пам'яті, так і шляхом реанімації забутого символу, події, ідеї або, коли з часом ці місця, залишаючись збереженими у людській свідомості, набувають зовсім іншого змістового навантаження [5, с. 38].

Пол Коннертон розглядає соціальну пам'ять як спільну пам'ять багатьох людей, що виникає на стику власне-особистісної, когнітивної пам'яті та пам'яті-звички. Ця пам'ять нерідко слугує елементом політичної ідеології, що контрольована владою, а втілюється вона у церемоніях / ритуалах вшанування, тілесних практиках (див.: [3]). Учений окремо звертає увагу на взаємозумовленості між сприйманням нинішнього й минулого, зафіксованого в індивідуальній та спільній пам'яті: «Теперішне намагається в певний спосіб впливати на наші спогади про минуле..., минуле намагається впливати чи спотворювати наше сприйняття теперішнього» [3, с. 16]. Водночас со284 
ціальна / колективна пам’ять у такому трактуванні постає спільною матрицею минулого у свідомості одного чи кількох поколінь [3, с. 17].

Розрізняючи соціальну пам'ять та історичну реконструкцію, П. Коннертон наголошує, що знання про всі види людської діяльності у минулому можливе лише через знання «слідів», які вони по собі залишають [3, с. 32]. Саме з останнім має справу історик, праця якого, на думку П. Коннертона, полягає у «робленні висновків». «Історики здатні заперечувати будь-що з того, що явно постає перед ними як свідчення, i заміняти його власним тлумаченням подій. I навіть у тому разі, якщо вони приймають те, про що промовляє їм попереднє твердження, вони це роблять не тому, що це твердження взагалі існує та має певний авторитет, а тому, що воно приймається і розглядається як таке, що задовольняє критерії та вимоги істориків до історичної істини» [3, с. 32]. Виходячи з цього, П. Коннертон доходить висновку, що історична реконструкція не залежить від соціальної пам'яті [3, с. 33].

Стосовно соціальної пам'яті сформульовано такі основні постулати: іiі носієм є група, обмежена в просторі і часі; вона формується колективом, що обумовлює пам'ять своїх членів у процесі комунікації в рамках відповідної соціальної групи; фундаментом для іiі формування $\epsilon$ певний усталений груповий порядок кодування інформації (спільна «базова знакова система»), завдяки якому і вибудовуються у всіх суб'єктів групи «схожі репрезентації минулого».

Зазвичай виокремлюють три типи минулого:

- практичне, утилітарне минуле, яке є частиною теперішнього («Будинки, в яких ми живемо, книжки, які ми читаємо, вислови, які ми повторюємо»);

- зафіксоване минуле, яке утворює продукти людської діяльності, що сприймаються як створені в минулому (раритети, антикваріат);

- сконструйоване минуле, яке фізично не присутне у теперішньому, представлене у свідомості й уяві через історичні тексти, різноманітні свідчення, мистецтво, медіа тощо.

Виходячи з цього, Юлія Сорока стверджує, що для подій і персонажів бути частиною минулого, мати статус «минулого» (а не, наприклад, старого, застарілого) означатиме бути соціально сприйманими у співвіднесенні з образом минулого, в категоріях минулого. Отже, набуття цього статусу подією чи персонажем залежить не від кількості років, що віддаляють їх від актуального теперішнього, а від наявності сконструйованого і легітимного образу події і персонажа та смислів, визнаних значимими в категоріях минулого. Таке бачення поміщає в центр уваги символічну роботу соціокультурного цілого зі 
створення й організації минулого, підтримки й відтворення актуальної його картини або іiі реформування, переформулювання [7, с. 54].

Виділяють два рівні соціальної пам'яті: офіційний та неофіційний. Риса-ми офіційної пам'яті є те, що вона формується цілеспрямовано згори; має системний характер; базується на панівній ідеології; формується переважно шляхом конструювання; поширюється переважно через офіційні канали; іiі носіями є шкільні підручники та офіційні 3МI; підтримується владними структурами. Неофіційна пам'ять володіє такими рисами: вона формується стихійно знизу; фрагментарний характер; базується на феномені сусп. спогадів; формується переважно шляхом реконструкції; поширюється головним чином через міжособистісні контакти; іiї носіями є архетипи, міфи, легенди, казки, чутки, плітки, анекдоти тощо; підтримується неформальними структурами.

Характеризуючи ці два рівні соціальної (колективної) пам'яті, Олександр Бойко виділяє своєрідну «буферну зону» («зону невизначеності»), яка розташовується між офіційним та неофіційним рівнем. «Інформація, яка перебуває в ній, як правило, має характер оцінки, акценту, постулату і націлена на конструювання за певною моделлю колективної пам'яті або на коригування / реконструкцію вже діючої моделі (простіше кажучи, на своєрідне «редагування» як минулого, так і майбутнього)» [1, с. 30]. До «буферної зони» потрапляють: а) вислови політиків; б) оцінки експертів; в) судження інтелектуалів (літераторів, істориків, культурологів) тощо стосовно формування / реконструкції / конструювання пам'яті, що набули поширення завдяки газетам, книгам, радіо, іншим засобам 3МI, але, навіть за цих обставин, не підтримуються ні «згори», ні «знизу». 3 плином часу з інформацією, що знаходиться у «буферній зоні» колективної пам'яті відбувається чотири процеси: а) перехід «вгору» на офіційний рівень; б) перехід «вниз» на неофіційний рівень; в) адекватне / безпроблемне входження як на офіційний, так і неофіційний рівень соціальної пам'яті; г) зникнення через неактуальність та природній процес забування.

Г. Коньшина виділяє дві основні форми соціальної пам'яті репродуктивну та реконструктивну. Перша безпосередньо охоплює процес звернення до минулого досвіду, тобто звичайне відтворення знань, які вже має суб'єкт, - репродукцію. Із виникненням писемності соціальна пам'ять переходить у свою реконструктивну форму, спрямовану на збереження й відновлення важливих 3 точки зору певного суспільства фактів і явищ. На думку Г. Коньшиної, «новий 
етап розвитку форм соціального запам'ятовування, який виник у результаті поширення писемності, сприяв складнішому сприйманню історичної дійсності. Відтворюючи минуле в умовах нового соціального середовища, письмові джерела стають елементами соціальної пам'яті» [4, с. 65].

Аналізуючи різні підходи до концептуалізації соціальної пам'яті, Світлана Хутка і Тетяна Полтавчук стверджують: «Історична пам'ять відрізняється від соціальної тим, що вона є неповною і недосконалою репрезентацією минулого, а також великою мірою залежить від суб' єктивного фактору і політичного замовлення. Соціальна пам'ять є більш широким поняттям, а деякі елементи соціальної пам'яті (наприклад, письмові джерела, архіви, документальні свідчення, археологічні матеріали) належать до історичної науки. Відповідно, історична пам'ять в певному розумінні може розглядатись як підсистема соціальної пам'яті» [10, с. 66].

Соціальна пам'ять $€$ елементом соціальної структури суспільства, складовою соціальних інститутів - у такий спосіб вона є зовнішньою відносно окремих індивідів, але водночас має вибірковий характер. Соціальна пам'ять тісно пов'язана з індивідуальною, тому події минулого відтворюються через призму особистісних інтересів чи інтересів певних соціальних груп, тобто відбувається ціннісно-символічна реконструкція минулого в сьогоденні, що може відбуватись як на індивідуальному, так і на колективному рівні. Враховуючи це, С. Хутка і Т. Полтавчук доводять, що соціальна пам'ять як невід'ємна складова колективної і індивідуальної свідомості «виконує стабілізуючу і репрезентативну функції, пов'язуючи минуле і соціальну реальність, і є складним багатокомпонентним феноменом, який тісно переплітається із сучасною реальністю, тим самим будучи включеною і в процес формування соціальної структури суспільства» [10, с. 67].

Віктор Городяненко звертає увагу на важливу обставину. Визначаючи соціальну пам'ять як сукупність соціокультурних засобів, що здійснюють відбір та перетворення актуальної суспільної інформації в інформацію про минуле 3 метою збереження накопиченого суспільного досвіду і передачі його від покоління до покоління, він зауважує: «Соціальна пам'ять може сприяти прискоренню одних соціальних процесів і, в той же час, гальмувати або блокувати інші. Нерідко проявляється і захисна соціальна амнезія - усунення із пам'яті травмуючих подій минулого» [2, с. 428]. 
Таким чином, на початкових етапах становлення меморіальних концептів дослідники здебільшого ототожнювали історичну і соціальну пам'ять, вважаючи їх зрізами колективної пам'яті. Поступово викристалізувалося розуміння можливості і потреби в проведенні демаркаційної лінії між даними концептами: сьогодні прийнято визначати соціальну пам'ять як форму трансляції символічного капіталу певних соціальних груп; вона є виразником групових цінностей, уявлень, настанов і в цьому значенні виступає носієм норм та цінностей соціальних груп, накопичує та зберігає соціальний капітал і забезпечує його використання в процесах спілкування й відтворення накопиченої соціальної інформації, а історичну пам'ять - як сукупність донаукових, наукових, квазінаукових і ненаукових знань та масових уявлень соціуму про спільне минуле. Співвідношення історичної і соціальної пам'яті проявляється виразно на індивідуальному рівні, коли події минулого відтворюються через призму особистісних інтересів чи інтересів певних соціальних груп, завдяки чому стає можливою ціннісно-символічна реконструкція минулого в сьогоденні. Крім того, соціальна пам'ять виконує важливу захисну функцію щодо травматичних сюжетів історичної пам'яті, що проявляється в соціальній амнезії, коли відбувається усунення із пам'яті небажаних подій минулого.

\section{БІБЛІОГРАФІЧНІ ПОСИЛАННЯ}

1. Бойко О. Д. Особливості структури колективної пам'яті / О. Д. Бойко // Наукові праці. Політологія. - 2014. - Т. 236. - № 224. - С. 27-32.

2. Городяненко В. Г. Соціальна пам'ять як інструмент ідеологічного впливу / В.Г.Городяненко//Сучаснісуспільніпроблемиувимірісоціологіїуправління: зб. наук. праць ДонДУУ. Серія «Спеціальні та галузеві соціології». - 2014. T. XV. - № 281. - C. 427-436.

3. Коннертон П. Як суспільства пам'ятають / П. Коннертон. - Київ: Нікацентр, 2004. - $184 \mathrm{c}$.

4. Коньшина Г. Є. Фактори становлення соціальної пам'яті / Г. Є. Коньшина // Вісник Хар-ківського національного університету імені В. Н. Каразіна. Серія «Психологія». - 2010. - Т. 913. - № 44. - С. 64-66.

5. Нора П. Всемирное торжество памяти / П. Нора // Неприкосновенный запас. Дебаты о политике и культуре. - 2005. - № 2-3. - С. 37-51.

6. Нора П. Память, история / П. Нора // 50/50: Опыт словаря нового мышления / П. Нора; под общ. ред. Ю. Афанасьева, М. Ферро. - М.: Прогресс,1989. - С. 441.

7. Сорока Ю. Ставлення до минулого / Ю. Сорока // Соціологія: теорія, методи, маркетинг. - 2009. - № 2. - С. 47-66. 
ISSN 2409-3661. Проблеми політичної історії України. Вип. 13. 2018 р.

8. Хальбвакс М. Коллективная и историческая память / М. Хальбвакс // Неприкосновенный запас. Дебаты о политике и культуре. - 2005. - № 2-3. - C. $12-35$.

9. Хальбвакс М. Социальные рамки памяти / М. Хальбвакс; пер. с фр. и вступ. статья С. Н. Зенкина. - М.: Новое издательство, 2007. - 348 с.

10. Хутка С. В. Соціальна пам'ять: основні підходи до концептуалізації / С. В. Хутка, Т. Г. Полтавчук // Методологія, теорія та практика соціологічного аналізу сучасного суспільства. - 2014. - № 20. - С. 63-67.

Надійшла до редкол.: 03.04.2018 